\title{
PERANCANGAN SISTEM INFORMASI PERGUDANGAN DENGAN METODE FRAMEWORK FOR THE APPLICATION SYSTEM THINKING (FAST) BERBASIS VBA MACRO EXCEL (STUDI KASUS PT. MEIDOH INDONESIA)
}

\author{
Fauzi Alfi Yasin ${ }^{1}$, Rianita Puspa Sari ${ }^{2^{*}}$ \\ Program Studi Teknik Industri, Universitas Singaperbangsa Karawang \\ fauzi.alfiyasin17015@student.unsika.ac.id ${ }^{1}$, rianita.puspasari@ ft.unsika.ac.id ${ }^{2}$
}

Submitted November 8, 2020; Revised December 1, 2020; Accepted December 2, 2020

\begin{abstract}
Abstrak
Perkembangan teknologi informasi bertumbuh sangat pesat, dibuktikan dengan lahirnya Industri 4.0. Industri 4.0 telah masuk ke dalam segala aspek kehidupan, industri manufaktur, dan industri jasa. Penggunaan teknologi informasi salah satunya bertujuan untuk meningkatkan efektifitas dan efisiensi suatu proses, dan keunggulan bersaing perusahaan. PT. Meidoh Indonesia yang berlokasi di Karawang mulai menerapkan teknologi Industri 4.0 khususnya pada bidang perbaikan alur aliran material. Proses pengambilan perlengkapan kerja karyawan masih dilakukan secara konvensional menggunakan kertas material request. Penelitian ini bertujuan untuk merancang suatu sistem informasi pergudangan perlengkapan kerja karyawan dengan menggunakan metode Framework For The Application System Thinking (FAST) berbasis VBA Macro Excel. Hasil penelitian menunjukkan sistem informasi ini memudahkan karyawan dalam pengambilan perlengkapan kerja dalam menunjang pekerjaannya. Sistem informasi dapat memangkas waktu pengambilan barang hingga $60 \%$. Waktu pengambilan barang dengan cara konvensional tercepat adalah 15 menit sedangkan pengambilan barang menggunakan sistem informasi pergudangan ini hanya membutuhkan waktu 5 menit.
\end{abstract}

Kata Kunci : Sistem Informasi Pergudangan, FAST, VBA Macro Excel

\begin{abstract}
The development of information technology is growing very rapidly, as evidenced by the birth of Industry 4.0. Industry 4.0 has entered all aspects of life, the manufacturing industry and the service industry. One of the purposes of the use of information technology is to increase the effectiveness and efficiency of a process and the company's competitive advantage. PT. Meidoh Indonesia, which is located in Karawang, has begun to apply Industry 4.0 technology, especially in the field of improving material flow. The process of taking employee work equipment is still conventionally using the material request paper. This study aims to design an employee work equipment warehousing information system using the Framework For The Application System Thinking (FAST) method based on VBA Macro Excel. The results showed that this information system makes it easier for employees to make requests for work equipment to support their work. Information systems can reduce times of request material up to 60\%. The fastest material request time conventionally takes 15 minutes, while material request time using this warehousing information system only takes 5 minutes.
\end{abstract}

Key Words : Warehouse Information System, FAST, VBA Macro Excel

\section{PENDAHULUAN}

Teknologi informasi dikembangkan untuk memudahkan mendapatkan informasi dan data yang dibutuhkan [1]. Implementasi Teknologi Informasi di suatu organisasi atau perusahaan adalah untuk meningkatkan efektifitas proses, efisiensi waktu dan keunggulan bersaing suatu perusahaan. Teknologi sangat berperan penting pada kehidupan manusia [2]. Suatu perusahaan tentunya selalu menginginkan efisiensi dan efektivitas semua kegiatannya. Tentunya agar perusahaan 
selalu dapat bersaing ataupun unggul dari perusahaan pesaingnya.

Perkembangan teknologi informasi bertumbuh sangat pesat, salah satunya karena telah lahirnya revolusi industri keempat atau yang lebih dikenal dengan Industri 4.0. Pendefinisian mengenai konsep Industri 4.0 belum pasti dan memiliki arti beragam karena masih filakukan penelitian dan pengembangan lebih lanjut [3]. Industri 4.0 adalah integrasi antara sistem fisik siber (Cyber Physics Sistem) dengan konsep Internet of Things serta Internet of Services (IoT dan IoS) yang masuk dalam proses industri manufaktur, logistik, dan proses indsutri lain [4].

Indonesia sendiri memiliki haluan tersendiri dalam menghadapi Industri 4.0, yaitu melalui Kementerian Perindustrian Indonesia membuat "Making Indonesia 4.0". Making Indonesia 4.0 adalah sebuah roadmap mengenai strategi Indonesia dalam implementasi memasuki Industri 4.0 untuk mencapai 10 besar ekonomi terkuat dunia pada tahun 2030 [5]. Ada 10 strategi prioritas yang ingin dicapai melalui peta jalan ini. Salah satunya adalah perbaikan alur material.

PT. Meidoh Indonesia (PTMI) merupakan perusahaan Jepang dalam bidang manufacturing sparepart otomotif dan salah satu perusahaan yang tergabung dalam Meidoh Group. PT. Meidoh Indonesia sudah mulai melakukan implementasi teknologi informasi dan Industri 4.0 di perusahaannya. Implementasi teknologi informasi dan Industri 4.0 di PT. Meidoh Indonesia dilakukan secara bertahap. Dimulai pada proses produksi menggunakan barcode, sistem inspeksi kualitas, dan absensi karyawan yang terintegrasi dengan sistem penggajian.

Pada saat ini, Industri 4.0 yang ingin diterapkan di PT. Meidoh Indonesia adalah pada bidang perbaikan alur aliran material yang juga merupakan salah satu strategi prioritas nasional Making Indonesia 4.0. Beragam inovasi dalam rangka mereduksi limbah kertas dilakukan di PT. Meidoh. Salah satunya Departemen HRGA PT. Meidoh Indonesia yang mulai membuat sasaran mutu dalam implementasi Industri 4.0.

Dalam memenuhi kebutuhan karyawan akan suatu barang ataupun perlengkapan dalam menunjang proses pekerjaan, PT. Meidoh Indonesia mempunyai gudang perlengkapan atau sering di sebut General Affair Storage selanjutnya disebut $G A$ Storage. GA Storage yang ada saat ini masih menggunakan sistem manual, yaitu menggunakan form yang berwarna kuning selanjutnya disebut kertas kuning. Saat akan mengambil barang, karyawan (pengambil) akan meminta form ke Departemen HRGA dan mengisinya, selanjutnya akan di approval oleh manager departemen masing-masing. Setelah form di approve manager kemungkinan pengambil melakukan kecurangan dengan menambah item sesukanya pada form tersebut.

Terdapat banyak kelemahan dalam pengisian form secara manual antara lain: waktu pengambilan dan approval yang lama, kesalahan input PIC gudang, setiap departemen tidak tahu stok tersedia setiap barang, pemborosan kertas, dan kemungkinan kertas kuning hilang. Maka dari itu, diperlukannya sistem informasi GA Storage yang mampu mengurangi kelemahan-kelemahan yang ada pada saat pengambilan barang di gudang secara manual, juga sebagai bentuk implementasi teknologi informasi dan Industri 4.0.

Penggunaan sistem informasi terkomputerisasi memiliki beberapa keuntungan seperti: pengolahan data keluar-masuk barang lebih efektif dan efisien, pencarian data lebih efisien, persediaan barang terkontrol dengan baik, 
dan data pelaporan lebih baik dan dapat diakses langsung [6].

Aplikasi yang dapat digunakan untuk membuat sistem pergudangan GA Storage ini adalah Microsoft Excel dengan menggunakan fitur macro VBA. Penggunaan fitur macro VBA pada Microsoft Excel agar menghasilkan sebuah aplikasi perancangan yang ringan. Hal ini sesuai dengan penelitian [7] yang menyatakan bahwa fitur macro VBA pada Ms. Office Excel mampu menghasilkan sebuah aplikasi perancangan sistem yang sederhana dan mudah digunakan. Selain itu tampilan yang sederhana dan ukuran file yang relatif kecil membuat perangkat lunak ini menjadi salah satu tools yang praktis untuk digunakan.

Penyelesaian masalah $G A$ Storage menggunakan metode Framework For The Applications of System Thinking (FAST). Metode FAST sering disebut juga pemodelan cerdas karena model ini mampu mendukung bukan hanya pengembangan aplikasi yang cepat, tetapi juga dengan dukungan teknik lainnya termasuk analisis sistem yang terstruktur, teknik informasi, dan analisis berorientasi objek dan desain [8].

Alat bantu perancangan sistem melalui metode FAST biasanya menggunakan Data Flow Diagram (DFD) atau Diagram Alir Data. DFD seringkali digunakan sebagai alat untuk merancang sistem informasi lama maupun baru, yang dikembangkan berdasarkan logika tanpa memperhatikan lingkungan fisik, yang menggambarkan aliran data tersebut [9].

Tujuan dari penelitian ini adalah melakukan perancangan suatu sistem pergudangan $G A$ Storage untuk Departemen Human Resources General Affair di PT. Meidoh Indonesia. Manfaat penelitian ini bagi perusahaan adalah sebagai bentuk implementasi teknologi industri 4.0 melalui sistem informasi pergudangan berbasis VBA Macro Excel. Sedangkan bagi penulis sebagai bentuk penelitian dan memberikan timbal-balik bagi perusahaan. Proses pengambilan perlengkapan lebih efektif dan efisien.

\section{METODE PENELITIAN}

Penelitian ini adalah merupakan salah satu bentuk penelitian eksperimen. Model eksperimen dari studi kasus permasalahan dalam penelitian ini adalah one shot case study. Model ini berarti membandingkan produktivitas sebelum menggunakan alat baru dengan produktivitas sebelum menggunakan alat baru dengan produktivitas setelah menggunakan alat baru [10].

Alur proses penelitian yang pertama adalah dengan pengumpulan data kebutuhan pengguna (user requirement), yaitu hal-hal atau komponen yang diperlukan pengguna dalam suatu sistem informasi. Pengumpulan data dilakukan di PT. Meidoh Indonesia dengan wawancara dan observasi dari para karyawan PT. Meidoh Indonesia. Kebutuhan pengguna tersebut diterjemahkan ke dalam system requirement, yaitu berupa kebutuhan fungsional dan non-fungsional. Setelah diketahui kebutuhan sistem, dilakukan metode penelitian menggunakan metode FAST atau Framework For The Application of System Thinking. Metode ini terdiri dari fase-fase berikut ini: [11]

\section{Scope Definition}

Tahap ini merupakan langkah awal dalam proses perancangan sistem informasi. Dalam tahap scope definition didefinisikan ruang lingkup dari sistem informasi yang akan di analisis

2. Problem Analysis

Analisa masalah dilakukan untuk pendefinisian lingkup dan masalah dalam pengembangan sistem informasi. 
3. Requirement Analysis

Analisa kebutuhan adalah menentukan kebutuhan sistem apa saja yang dibutuhkan pada sistem informasi, yaitu kebutuhan pengguna dan kebutuhan sistem.

\section{Logical Design}

Metode perancangan yang menggunakan metode perancangan berorientasi objek dengan menggunakan Data Flow Diagram sebagai alat bantu perancangan.

\section{Physical Design}

Merupakan tahapan menterjemahkan logical design ke dalam bentuk fisik suatu aplikasi, meliputi perancangan user interface dan detail design.

Langkah pertama metode FAST adalah scope definition, berisi definisi ruang lingkup secara umum dari sistem informasi yang dibuat, yaitu sistem informasi pergudangan GA Storage pada PT. Meidoh Indonesia. Tahap kedua adalah problem analysis, analisis permasalahan yang terjadi pada sistem manual pergudangan GA Storage, digunakan tools cause and effect analyze (analisa sebab-akibat). Tahap ketiga adalah requirement analysis, berarti menganalisis kebutuhan-kebutuhan apa saja yang dibutuhkan sistem dalam menjalankan prosesnya. Tahap keempat adalah logical design, yaitu dengan cara membuat proses bisnis suatu sistem informasi berupa kegiatan fungsional dan non-fungsionalnya dan alur data sistem. Logical design menggunakan DFD sebagai penggambarannya.

DFD menggambarkan aliran data yang terjadi dalam suatu sistem informasi, sehingga dapat mempermudah dalam mengetahui alur proses yang terjadi pada sistem informasi [12]. Notasi yang dipakai dalam pembuatan DFD adalah:
Tabel 1. Notasi Data Flow Diagram

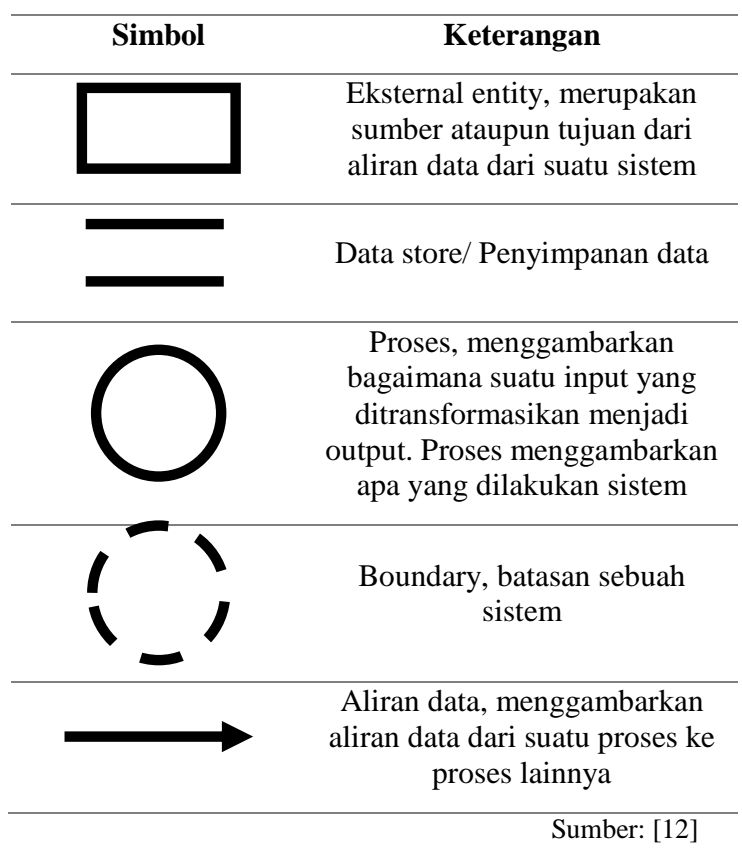

Tahap terakhir adalah Physical Design, berarti proses penerjemahan bentuk logika (logical design) ke dalam bentuk fisik atau user interface.

Aplikasi yang digunakan untuk membuat sistem informasi pergudangan GA Storage ini adalah Aplikasi Microsoft Excel dengan penggunaan Macro VBA di dalamnya. Macros di dalam VBA adalah program untuk mengotomatisasi perintah-perintah yang sifatnya rutin dan berulang pada sebuah workbook [13].

\section{HASIL DAN PEMBAHASAN}

Hasil penelitian ini disajikan dengan berbagai fase dalam metode FAST.

\section{Scope Definition}

Ruang lingkup penelitian ini adalah pembuatan sistem informasi pergudangan di PT. Meidoh Indonesia.

1. Nama proyek

Nama proyek perancangan sistem informasi ini adalah perancangan sistem informasi pergudangan GA Storage.

2. Ruang Lingkup

Ruang lingkup perancangan sistem informasi ini adalah pada PT. Meidoh 
Indonesia tepatnya Departemen HRGA tentang permasalahan gudang perlengkapan penunjang proses pekerjaan karyawan.

\section{Problem Analysis}

Analisis permasalahan menggunakan cause and effect analyze.

Tabel 2. Cause And Effect Analyze

\begin{tabular}{cc}
\hline \multicolumn{2}{c}{ Cause And Effect Analyze } \\
$\begin{array}{c}\text { Problem or } \\
\text { opportunities }\end{array}$ & Causes and Effects \\
\hline $\begin{array}{c}\text { Waktu pengambilan dan } \\
\text { approval yang lama (15- } \\
60 \text { menit) }\end{array}$ & $\begin{array}{c}\text { Mengurangi waktu kerja } \\
\text { karyawan }\end{array}$ \\
\hline $\begin{array}{c}\text { Setelah di approve } \\
\text { manajer kemungkinan } \\
\text { terdapat kecurangan } \\
\text { yang dilakukan } \\
\text { pengambil }\end{array}$ & $\begin{array}{c}\text { Kecurangan akan } \\
\text { berakibat pada } \\
\text { menurunnya nilai KPI } \\
\text { karyawan, dan stok yang } \\
\text { tidak terkontrol }\end{array}$ \\
\hline $\begin{array}{c}\text { Kesalahan Input stok } \\
\text { barang dari PIC gudang }\end{array}$ & $\begin{array}{c}\text { Dept. HRGA kesulitan } \\
\text { dalam melakukan stock } \\
\text { opname }\end{array}$ \\
\hline $\begin{array}{c}\text { Setiap departemen tidak } \\
\text { tahu stok barang yang } \\
\text { tersedia di gudang }\end{array}$ & $\begin{array}{c}\text { Waktu untuk request } \\
\text { material berkurang }\end{array}$ \\
\hline $\begin{array}{c}\text { Penggunaan kertas yang } \\
\text { kurang efisien (terlalu } \\
\text { banyak) }\end{array}$ & $\begin{array}{c}\text { Pengeluaran untuk kertas } \\
\text { terlalu banyak. }\end{array}$ \\
\hline $\begin{array}{c}\text { Kertas Kuning (Form } \\
\text { Material Request) yang } \\
\text { hilang }\end{array}$ & $\begin{array}{c}\text { PIC gudang akan } \\
\text { kesusahan dalam } \\
\text { melakukan update stock }\end{array}$ \\
\hline
\end{tabular}

Tabel 2 menunjukkan bahwa masih banyak kelemahan yang ada pada sistem manual GA Storage. Maka perlu dilakukan perbaikan sistem yang lebih baik, yaitu melalui sistem informasi berbasis Macro Excel agar menutupi kelemahan yang ada pada sistem manual.

\section{Requirement Analysis}

Kebutuhan sistem dapat berupa entitas/aktor, kebutuhan pengguna, kebutuhan perangkat keras, dan kebutuhan perangkat lunak.

\section{Entitas/Aktor}

Entitas/aktor pada sistem informasi pergudangan GA Storage adalah:
Tabel 3. Entitas dan Aktor

\begin{tabular}{cc}
\hline Entitas & Deskripsi \\
\hline Admin (Dept. & $\begin{array}{c}\text { Merupakan user yang memiliki akses } \\
\text { administrator, dapat merubah sistem, } \\
\text { dan mengetahui seluruh kegiatan di } \\
\text { dalam sistem. }\end{array}$ \\
\hline Pengambil & $\begin{array}{c}\text { Merupakan user yang memiliki akses } \\
\text { login ke dalam sistem untuk } \\
\text { membuat request barang }\end{array}$ \\
\hline Manajer & $\begin{array}{c}\text { Merupakan user yang memiliki } \\
\text { otoritas memverifikasi data dari } \\
\text { pengambil }\end{array}$ \\
\hline PIC Gudang & $\begin{array}{c}\text { Merupakan user yang menerima } \\
\text { informasi request barang dan } \\
\text { menyiapkannya untuk pengambil }\end{array}$ \\
\hline
\end{tabular}

2. Kebutuhan pengguna

Kebutuhan pengguna pada sistem informasi pergudangan GA Storage adalah:

\section{Tabel 4. Kebutuhan Pengguna}

\begin{tabular}{cc}
\hline Entitas & Deskripsi \\
\hline $\begin{array}{c}\text { Admin (Dept. } \\
\text { HRGA) }\end{array}$ & $\begin{array}{c}\text { Dapat merubah sistem } \\
\text { Memiliki hak akses penuh pada } \\
\text { sistem }\end{array}$ \\
& $\begin{array}{c}\text { Dapat melakukan update stok barang } \\
\text { Dapat menambah/menghapus user }\end{array}$ \\
\hline Pengambil & Dapat melakukan login \\
& Dapat melakukan request barang \\
& Dapat melihat stok barang \\
\hline Manajer & Dapat memverifikasi request barang \\
& bawahannya \\
& Dapat menerima list request barang \\
\hline PIC Gudang & Dapat menerima list request barang \\
\hline
\end{tabular}

3. Kebutuhan perangkat keras

Berdasarkan hasil pengujian langsung secara uji coba, kebutuhan perangkat keras yang disarankan adalah:

Tabel 5. Kebutuhan Perangkat Keras

\begin{tabular}{cc}
\hline $\begin{array}{c}\text { Jenis } \\
\text { perangkat }\end{array}$ & Kebutuhan \\
\hline Processor & $\begin{array}{c}\text { Intel(R) Core(TM) i3-6006U CPU } \\
\text { @ 2.00GHz (4 CPUs), 2.0GHz }\end{array}$ \\
\hline Memory & 4096MB RAM \\
\hline Card name & Intel(R) HD Graphics 520 \\
\hline Harddisk drive & $500 \mathrm{~GB}$ \\
\hline Keyboard & All device \\
\hline Mouse & All device \\
\hline
\end{tabular}


4. Kebutuhan perangkat lunak

Berdasarkan hasil pengujian langsung secara uji coba, kebutuhan perangkat keras yang disarankan adalah sebagai berikut:

\section{Tabel 6. Kebutuhan Perangkat Lunak}

\begin{tabular}{cc}
\hline $\begin{array}{c}\text { Jenis } \\
\text { perangkat }\end{array}$ & Kebutuhan \\
\hline Sistem Operasi & Windows 10 Pro 64-bit \\
\hline Internet & 100 MBps \\
\hline Jenis Excel & Ms. Excel 2010
\end{tabular}

\section{Logical Design}

Perancangan alur data dilakukan dengan pembuatan diagram alir data atau Data Flow Diagram. Langkah awal pembuatan DFD adalah membuat diagram level 0 atau Diagram Konteks. Diagram konteks adalah penggambaran sistem secara umum mengenai arus balik suatu sistem [14]. Selanjutnya dibuat DFD level 1, 2, dan seterusnya. Diagram konteks dari sistem informasi GA Storage seperti ditunjukkan pada Gambar 1.

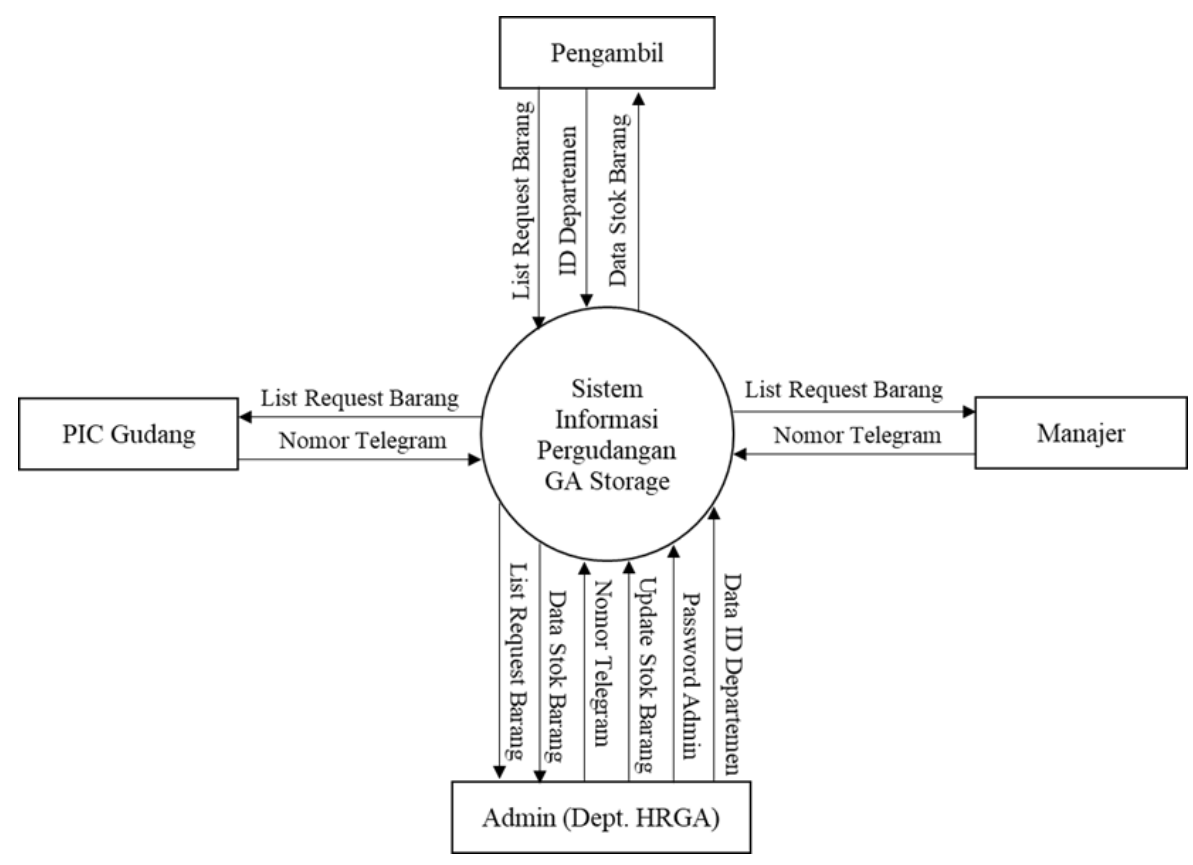

Gambar 1. Diagram Konteks

Sistem informasi pergudangan GA Storage mempunyai 4 (empat) entitas yaitu, PIC gudang, Pengambil, Manajer, dan Admin (Departemen HRGA). Selanjutnya, dari diagram konteks dikembangkan menjadi Data Flow Diagram (DFD) Level 1. DFD Level 1 adalah merupakan gambaran rinci dari diagram konteks. Dikaitkan dengan bagan hirarki proses merupakan diagram yang menguraikan rincian dari level kesatu. DFD Level 1 Sistem Informasi
Pergudangan GA Storage ditunjukkan pada Gambar 2.

DFD Level 1 menjelaskan gambaran rinci dari diagram konteks. Aktivitas yang terjadi di sistem informasi pergudanga $G A$ Storage berawal dari login pengambil, pengambil melakukan request barang, Manajer, PIC (Person In Charge) gudang, dan admin mendapat data list barang. Terakhir, barang disiapkan oleh PIC gudang. 


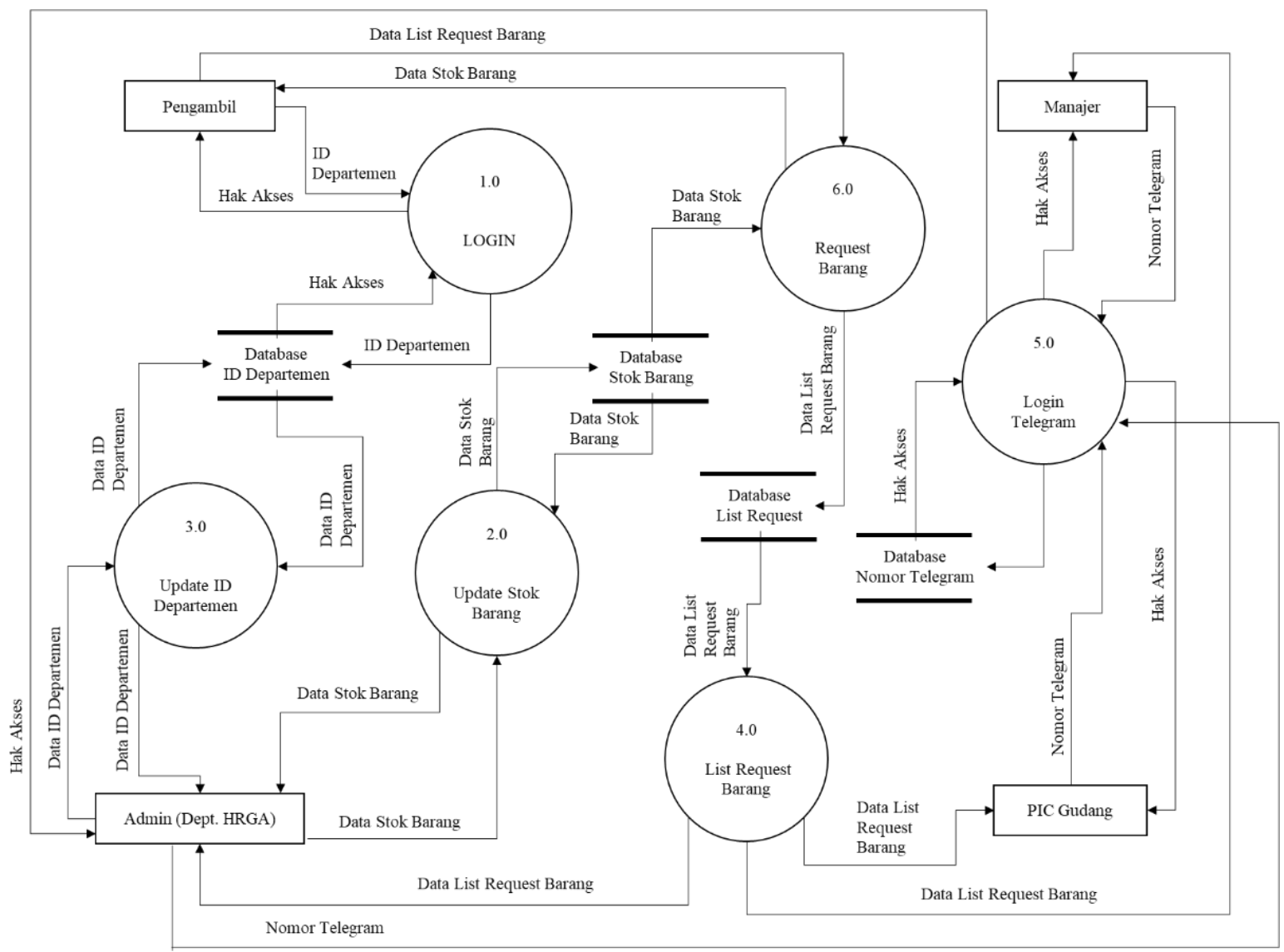

\section{Gambar 2. DFD Level 1}

\section{Physical Design}

Setelah dilakukan perancangan logika, selanjutnya diterjemahkan ke dalam bentuk fisik atau physical design. Fase physical design merupakan tahapan menterjemahkan logical design ke dalam bentuk fisik suatu aplikasi, meliputi perancangan user interface dan detail design [15].

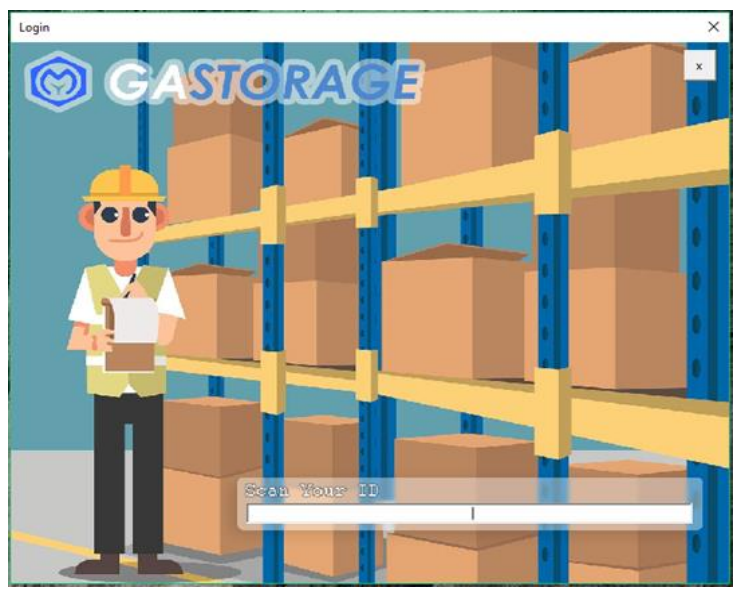

Gambar 3. Halaman Login
Pada halaman login GA Storage pengambil barang melakukan scan terhadap barcode departemennya. Apabila berhasil melakukan scan barcode maka muncul halaman menu GA Storage. User Interface halaman menu GA Storage adalah sebagai berikut:

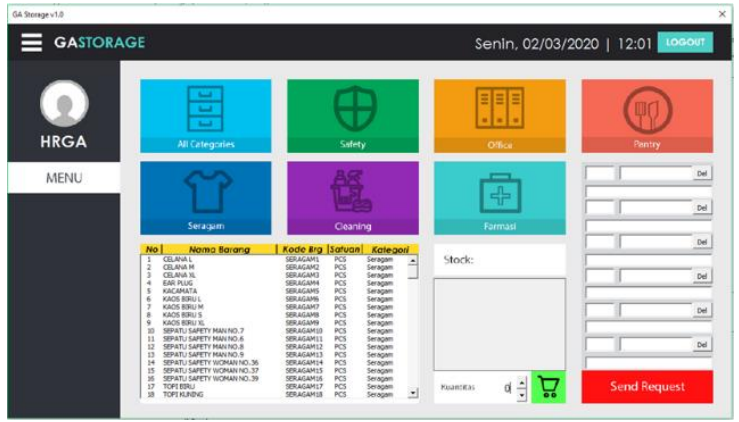

Gambar 4. Halaman Menu

Pada halaman menu GA Storage pengambil barang memilih barang yang akan di ambil. Pengambil dapat memlih kategori barang yang akan diambil dengan menekan icon kategori yang ada pada 
halaman menu. Selanjutnya apabila telah memilih kategori barang, pengambil memilih barang yang akan diambil dan akan keluar stok dan gambar barang yang dipilih. Pengambil menentukan kuantitas barang yang akan diambil dan melakukan request barang. Setelah itu maka muncul jendela konfirmasi material request, seperti berikut ini:

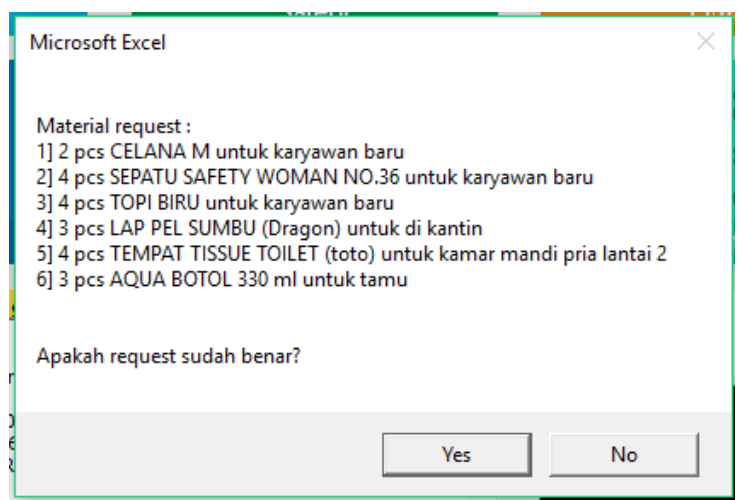

Gambar 5. Jendela Konfirmasi Material Request

Apabila material request telah sesuai dengan kebutuhan pengambil untuk barang yang akan diambil, maka dapat menekan tombol 'Yes', apabila tidak sesuai maka dapat menekan tombol 'No' untuk melakukan request barang ulang. Setelah pengambil menekan tombol 'Yes' maka akan muncul jendela informasi bahwa PIC akan menyiapkan pesanan barang sebagai berikut:

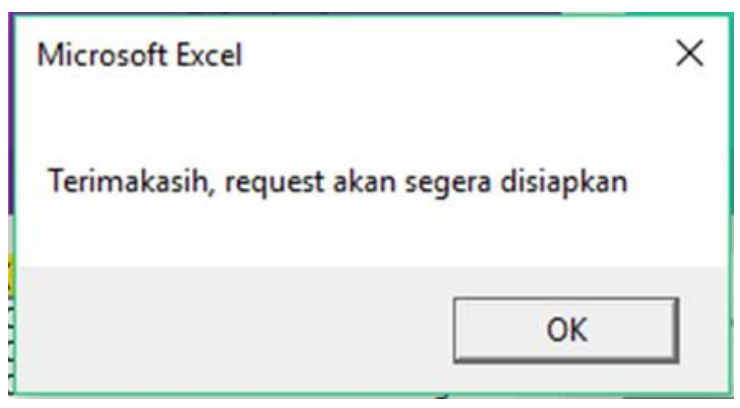

\section{Gambar 6. Jendela Informasi Pesanan akan Disiapkan}

Setelah muncul jendela informasi di atas, pengambil menunggu request barang disiapkan PIC gudang dan mengambil barang di gudang.

\section{Perbandingan Sistem Manual dan Sistem GA Storage}

Tabel 7. Perbandingan Sistem Manual dan Sistem GA Storage

\begin{tabular}{|c|c|c|}
\hline No & Pengisian Manual & Sistem GA Storage \\
\hline 1. & $\begin{array}{l}\text { Waktu pengambilan } \\
\text { dan approval yang } \\
\text { lama }(15-60 \text { menit })\end{array}$ & $\begin{array}{l}\text { Waktu pengambilan } \\
\text { dan approval lebih } \\
\text { singkat }(5-10 \text { menit })\end{array}$ \\
\hline 2. & $\begin{array}{l}\text { Setelah di approve } \\
\text { manajer } \\
\text { kemungkinan } \\
\text { terdapat kecurangan } \\
\text { yang dilakukan } \\
\text { pengambil }\end{array}$ & $\begin{array}{c}\text { Manajer dapat } \\
\text { mengetahui barang } \\
\text { yang akan diambil oleh } \\
\text { karyawan secara } \\
\text { langsung lewat Grup } \\
\text { Telegram }\end{array}$ \\
\hline 3. & $\begin{array}{l}\text { Kesalahan Input stok } \\
\text { barang dari PIC } \\
\text { gudang }\end{array}$ & $\begin{array}{c}\text { Input stok barang } \\
\text { otomatis }\end{array}$ \\
\hline 4. & $\begin{array}{l}\text { Setiap departemen } \\
\text { tidak tahu stok } \\
\text { barang yang tersedia } \\
\text { di gudang }\end{array}$ & $\begin{array}{l}\text { Stok barang tersedia } \\
\text { pada sistem secara } \\
\text { real-time }\end{array}$ \\
\hline 5. & $\begin{array}{l}\text { Penggunaan kertas } \\
\text { yang kurang efisien } \\
\text { (terlalu banyak) }\end{array}$ & $\begin{array}{l}\text { Tidak menggunakan } \\
\text { kertas }\end{array}$ \\
\hline 6. & $\begin{array}{l}\text { Kertas Kuning (Form } \\
\text { Material Request) } \\
\text { yang hilang }\end{array}$ & \\
\hline
\end{tabular}

Tabel 7 di atas dapat diketahui bahwa sistem informasi pergudangan GA Storage memiliki kelebihan dibandingkan pengisian manual. Maka dari itu, sistem informasi pergudangan GA Storage dapat mengatasi permasalahan pada pengisian manual. Tetapi suatu sistem juga bukan berarti tidak memiliki kelemahan. Kelemahan yang terdapat pada sistem informasi pergudangan GA Storage terdapat pada Tabel 8 .

\section{Tabel 8. Kelemahan Sistem GA Storage}

\begin{tabular}{cl}
\hline No & \multicolumn{1}{c}{$\begin{array}{c}\text { Kelemahan Storage } \\
\text { GA Stem Informasi Pergudangan }\end{array}$} \\
\hline 1. & $\begin{array}{l}\text { Pengambil hanya dapat mengambil maksimal } 6 \\
\text { jenis barang }\end{array}$ \\
\hline 2. & $\begin{array}{l}\text { Lemahnya approval dari setiap manajer, } \\
\text { approval manajer dipertanyakan. }\end{array}$ \\
\hline 3. & $\begin{array}{l}\text { Manajer tidak dapat melakukan approval } \\
\text { apabila sinyal error atau tidak adanya paket } \\
\text { internet }\end{array}$ \\
\hline Aplikasi hanya dapat dijalankan di satu \\
komputer saja.
\end{tabular}

Masih terdapat kelemahan, tetapi sistem informasi pergudangan GA Storage dapat 
memangkas waktu pengambilan barang sebesar $60 \%$.

Tabel 9. Perbandingan Waktu Pengambilan Barang

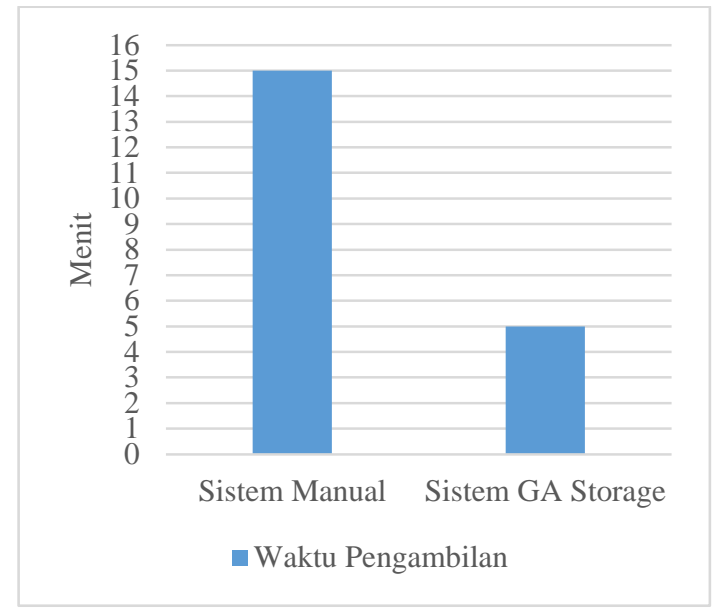

Berdasarkan observasi, waktu pengambilan barang secara manual paling cepat selama 15 menit sedangkan pengambilan barang menggunakan sistem informasi pergudangan GA Storage hanya membutuhkan waktu 5 menit, mengindikasikan bahwa penggunaan $G A$ Storage efektif untuk mengurangi waktu pengambilan perlengkapan kerja karyawan di PT. Meidoh Indonesia.

\section{SIMPULAN}

Perancangan sistem informasi GA Storage terbukti dapat memudahkan karyawan PT. Meidoh Indonesia dalam pengambilan perlengkapan kerja untuk menunjang pekerjaannya, karena dapat memangkas waktu pengambilan barang dari 15 menit menjadi hanya 5 menit. Keunggulan lainnya dari sistem informasi GA Storage adalah manajer dapat mengetahui data transaksi barang secara langsung, inputoutput barang terekam dengan jelas, dan tidak membutuhkan kertas dalam pelaporan. Perancangan sistem yang dibuat masih mengacu pada kegiatan satu departemen dalam pergudangan sehingga pada penelitian selanjutnya dapat membuat sistem informasi ini terintegrasi pada setiap departemen, serta ditingkatkan keamanan (cybersecurity) dan meramalkan peningkatan kapasitas barang yang dapat diambil pada sistem informasi tersebut.

\section{DAFTAR PUSTAKA}

[1] C. R. A. Dinda, S. Andryana, and Benrahman, "Perancangan Aplikasi Document Management System Berbasis Web Universitas Nasional Dengan Metode Waterfall," STRING (Satuan Tulisan Ris. dan Inov. Teknol., vol. 5, no. 1, pp. 4552, 2020.

[2] T. Anjani, Z. Niswati, and I. Mutia, "PERANCANGAN APLIKASI PEMINJAMAN BUKU PERPUSTAKAAN PADA SDN MEKARJAYA 11 DEPOK," STRING (Satuan Tulisan Ris. dan Inov. Teknol., vol. 5, no. 1, pp. 101107, 2020.

[3] H. Prasetyo and W. Sutopo, "Industri 4.0: Telaah Klasifikasi Aspek Dan Arah Perkembangan Riset,"J@ti Undip J. Tek. Ind., vol. 13, no. 1, p. 17, 2018, doi: 10.14710/jati.13.1.17-26.

[4] Kagermann, W. Wahlster, and J. Helbig, "Recommendations for implementing the strategic initiative INDUSTRIE 4.0," Final Rep. Ind. 4.0 WG, no. April, 2013.

[5] K. P. R. Indonesia, "Making Indonesia 4.0," 2016. doi: $10.7591 / 9781501719370$.

[6] A. O. Sari and E. Nuari, "Rancang Bangun Sistem Informasi Persediaan Barang Berbasis Web Dengan Metode Fast (Framework For The Applications)," J. PILAR Nusa Mandiri, vol. Vol. 13, no. 2, pp. 261-266, 2017, [Online]. Available:

http://ejournal.nusamandiri.ac.id/eju rnal/index.php/pilar/article/view/705 
[7] K. Anam, E. S. Hadi, P. Manik, D. T. Perkapalan, F. Teknik, and U. Diponegoro, "Pembuatan Aplikasi Perancang Lines Plan Dengan Metode Diagram Nsp (Nederlandsch Scheepbouwkundig Proefstation) Berbasis Macro Vba Ms. Office Excel Dan Pendekatan B-Spline Untuk Mempermudah Proses Perancangan Kapal," J. Tek. Perkapalan, vol. 4, no. 4, pp. 811820, 2017.

[8] Y. Muchsam, "PENGEMBANGAN SISTEM INFORMASI KERAWANAN PANGAN BERBASIS SMS GATEWAY DENGAN MENGGUNAKAN METODE FAST (Framework for the Applications of System Thinking) (Studi Kasus di Dinas Pangan Kabupaten Karawang)," $J$. E-KOMTEK, vol. 1, no. 1, pp. 99111, 2017.

[9] M. F. Martasubrata and Y. Priyadi, "Analisis Kesiapan UMKM Dalam Mengadopsi E-SCM Melalui Kolaborasi Technology Acceptance Model dan Data Flow Diagram di UMKM Clothing Line Lokal Bandung," Sosiohumanitas, vol. 21, no. 2, pp. 108-115, 2020, doi: 10.36555/sosiohumanitas.v21i2.124

[10] Sugiyono, Cara Mudah Menyusun: Skripsi, Thesis, dan Disertasi, 3rd ed. Bandung: ALFABETA, 2015.
[11] A. S. Abdullah, H. Setiawan, N. Ummi, J. Industri, U. Sultan, and A. Tirtayasa, "Perancangan Sistem Informasi Berbasis Website dengan Metode Framework For The Applications of System Thinking," J. Tek. Ind., vol. 1, no. 4, pp. 358367, 2013.

[12] H. Bagir and B. E. Putro, "Analisis Perancangan Sistem Informasi Pergudangan di CV. Karya Nugraha," J. Media Tek. dan Sist. Ind., vol. 2, no. 1, p. 30, 2018, doi: 10.35194/jmtsi.v2i1.274.

[13] M. S. Umam, T. S. Nugrahani, P. S. Akuntansi, and F. Ekonomi, "Pendampingan Pembuatan Aplikasi Pencatatan Proses Bisnis Menggunakan Vba Macro Excel Pada Apotek Srandakan," pp. 8286.

[14] Z. H. Siregar, "Implementasi Macro Excel (VBA) Sebagai Sistem Informasi Registrasi Dan Monitoring Talangan Haji Pada PT. Bank Mandiri Cab. Ternate," IESM J. (Industrial Eng. ..., vol. 1, no. 1, pp. 48-67, 2019, [Online]. Available: http://e-journal.potensiutama.ac.id/ojs/index.php/IESM/arti cle/view/517.

[15] D. P. Sari, O. M. Febriani, and A. S. Putra, "Perancangan Sistem Informasi SDM Berprestasi pada SD Global Surya,” pp. 289-294, 2018. 